\title{
The Utility of Different Types of Implants in Repairing Knee Joint Posttraumatic Lesions
}

\author{
JENEL MARIAN PATRASCU J.$^{1}$, MIHAI ALEXANDRUSANDESC ${ }^{1 *}$, MARIANATUDORAN ${ }^{1 *}$, DAN COJ OCARU ${ }^{2}$, ADRIAN LAZARESCU ${ }^{1}$, \\ GABRIELA ANCA BISTREAN ${ }^{2}$, CARMEN CAMELIA HAIVAS ${ }^{1}$, CODRUTA MILOICOV BACIAN ${ }^{1}$, MIHAELA BOANCA ${ }^{3 *}$, \\ ALINA MIHAELA PASCU ${ }^{4}$, GHEORGHE BOGDAN HOGEA ${ }^{1}$ \\ 'Victor Babes University of Medicine and Pharmacy, 2 Eftimie Murgu Sq., 300041, Timisoara, Romania \\ 2Pius Brinzeu Emergency County Hospital 156 Liviu Rebreanu Blvd., 300723 Timisoara, Romania \\ ${ }^{3}$ Grigore T. Popa University of Medicine and Pharmacy, Faculty of Medicine, 16 Universitatii Str., 700115 lasi, Romania \\ ${ }^{4}$ Transilvania University of Brasov, Faculty of Medicine, 29 Eroilor Blvd, 500036 Brasov, Romania
}

\begin{abstract}
Traumatic lesions of the knee joint represent one of the most frequent lesions, found especially in young, active people. The most often structures affected are menisci, cruciate ligaments, and cartilage. Identifying of new reconstructive techniques and implants for the treatment of these complex lesions represents a constant challenge for orthopedic surgeons. Our paper tries to present the utility of some implant techniques along with our experience and the results obtained in our clinic.
\end{abstract}

Keywords: meniscal tears, anterior cruciate ligament rupture, osteochondral lesion

The knee joint is the largest joint of the human body and is one of the major joints that take over the weight of the entire body. Many traumas, inflammatory and tumoral processes occur at this level because the knee joint is less protected than other joints [1].

Traumatic lesions of the knee joint are among the most frequent lesions, found especially in young, active people. Structures that are most often affected are menisci, cruciate ligaments and cartilage.

About 50 percent of all injuries that affects the anterior cruciate ligament $(A C L)$ will also interest menisci or cartilage damage. Meniscal tissue consists mainly of water and type I collagen fibers [2].

Meniscal tears are often classified according to their orientation. They may be disposed vertical longitudinal, vertical radial, horizontal, oblique or complex. Longitudinal tears are more common medially, whereas radial tears are more frequently seen laterally.

Ruptures of the $A C L$ and posterior cruciate ligament (PCL) can occur during sport activities. These two ligaments are called the "central pivot" of the knee. ACL is the main stabilizer of the knee in pivotal activities, having an important role in the knee biomechanics. The ACL is the most affected, being very often injured, especially in the young, active population.

Chondral and osteochondral lesions represent debilitating conditions. Untreated, they would progress to more extensive joint damage, eventually leading to the development of osteoarthritis [3].

Osteochondral defects are often symptomatic and adversely affect the functionality of the joint. The spontaneous healing capacity of osteochondral defects is limited [3].

Trauma is the most common cause of osteochondral lesions. It is usually caused by sports injury or accidents. The shearing force creates a stress fracture through cartilage matrix, and sometimes through subchondral bone [4].

\section{Experimental part}

We studied a lot of 548 patients that were admitted and treated in Orthopedics II Department from the Emergency County Hospital Timisoara between 2010 and 2019.
These patients had lesions in the knee joint, affecting menisci, ACL, PCL, and also osteochondral lesions.

Magnetic resonance imaging (MRI) was used to assess the knee joint lesions preoperatively, while for the severity of cartilage damage, we used International Cartilage Repair Society (ICRS) severity scoring system, consisting of two parts: the first part, A: PATIENT PART -contains ICRS Injury questionnaire, and International Knee Documentation Committee (IKDC) Subjective Knee Evaluation Form-2000; the second part, B: SURGEONS PART -contains ICRS Knee Surgery History Registration, IKDC Knee Examination Form-2000, ICRS-Articular Cartilage Injury Mapping System, ICRS - Articular Cartilage Injury Classification, ICRS Osteochondritis Dissecans Classification, ICRS -Cartilage Repair Assessment System [3].

Various surgical treatment methods were performed, based on lesion type, association and classification of the lesions.

The surgery was performed through arthroscopy or miniarthrotomy or combined, according to the case requirement.

In meniscal tears, the treatment consisted of meniscectomy or meniscal suture.

In cruciate ligaments rupture, consisting of isolated $\mathrm{ACL}$ rupture or both $A C L$ and $P C L$ rupture, the treatment methods were reconstruction using different types of grafts.

Autografts that were used in some cases were either of patellar tendon using bone -tendon -bone technique or hamstring technique. In several cases we used allograft of patellar tendon using bone -tendon -bone technique from cadaver. Artificial ligaments (ligament advanced reinforcement system -LARS) were used for $A C L$ in some cases, while for PCL in all cases. LARS ligament is a synthetic ligament made of non-absorbing polyethylene terephthalate fibers whose structure allow tissue in growth in the intra-articular part, improving the stability of the joint [5].

For osteocartilaginous lesions, we used different methods of treatment, from the classical microfracture or mosaicplasty techniques, up to the modern reconstructive techniques, such as Hyalograft C, Chondrotissue implants and Agili-C implants. 
Hyalograft C implant was implanted using a two steps procedure. In the first stage the harvest of the cartilage cells was performed. After the harvesting, cells were sent for processing, and the implantation intervention was performed in the 7th day after the first procedure. The implantation was done using a miniarthrotomy.

For the patients receiving Chondrotissue implants, a standard mini-open arthrotomy was used. The defective cartilage was carefully debrided down to the subchondral bone. A standard microfracture procedure was then performed. A freeze-dried chondrotissue matrix was immersed in $3 \mathrm{~mL}$ autologous serum for ten minutes and placed into the defect. For transosseous fixation of the matrix, absorbable threads were secured with threefold knot to act as anchors to the subchondral bone [6].

For Agili-C, the procedure was performed through minimal arthrotomy centered on the cartilage defect, after arthroscopic examination of the joint.

In the group that was treated with Agili-C, in case of associated lesions (meniscus $+A C L+$ osteochondral lesions), we performed a first surgery to resolve the meniscal lesions and ACL first, and after 6 months we implanted Agili-C. In case of meniscal + osteochondral lesions the intervention was performed in one single surgical procedure.

\section{Results and Discussions}

Our group of 548 patients was divided according to the complexity and association of the lesions. One hundred thirty-six patients had only meniscal lesions, 185 had combined meniscal and ACL lesions, 10 had meniscal, $A C L$ and PCL lesions, 40 had association of meniscal, $A C L$ and osteocartilaginous lesions, and 177 had meniscal and cartilaginous lesions, as shown in figure 1 .

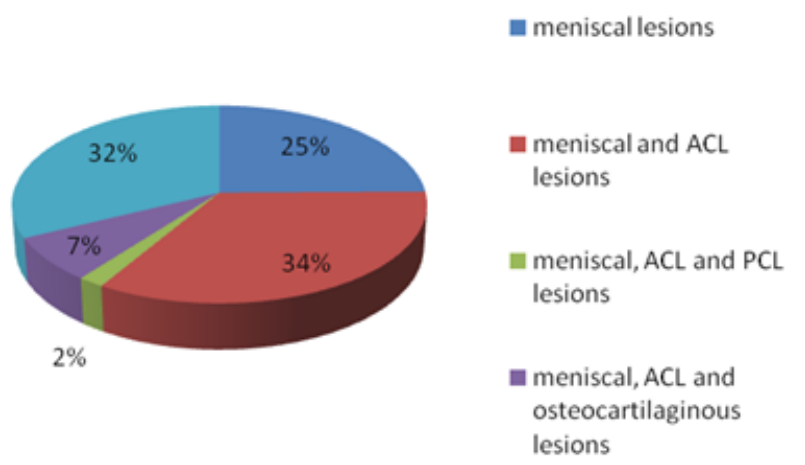

Fig. 1. Distribution of the identified knee joint lesions in the study group

LARS artificial ligament was used in 35 cases for $A C L$, and in all PCL cases.

Hyalograft $\mathrm{C}$ was used in 7 cases, Chondrotissue in 12 cases, and Agili-C in 60 cases from all the cases with osteochondral defect.

The medication administered during hospitalization consisted of non-steroidal anti- inflammatory painkillers, according to the hospital protocols [7-12], with respect to any pre-existent conditions such as diabetes mellitus [1320] or cardiovascular conditions such as arterial hypertension [21-26].

Rehabilitation was performed using specific protocols, allowing for full load on the second day postoperative for patients with meniscal surgery only and for patients who also had autologous chondrocyte implantation ( $\mathrm{ACl}$ ). Physical activity such as performance sport was allowed after 6-8 months in bone-patellar tendon-bone (BTB) autograft cases, and after 6 weeks in LARS cases.
For patients operated using Hyalograft $C$, Chondrotissue and Agili-C techniques, weight bearing was allowed after 6 weeks postoperative.

All patients were evaluated pre- and post-intervention, using a KT 1000 Arthrometer to measure knee instability. Knee function was assessed using the International Knee Documentation Committee (IKDC) score and Lysholm Score. Physical activity levels were measured using the Tegner Activity Scale.

Each patient was functionally and clinically evaluated using IKDC score and Knee Injury and Osteoarthritis Outcome Score (KOOS) at 3, 6, 9, and 12 months after surgery.

The KOOS covers five dimensions that are reported separately: pain, symptoms, activities of daily living, sport and recreation function, and knee-related quality of life. It is used to ensure content validity for subjects with $\mathrm{ACL}$ injury, meniscus injury, and early osteoarthritis. The five dimensions of KOOS were scored separately: pain (nine items); symptoms (seven items); activities of daily life function (17 items); sport and recreation function (five items); and knee-related quality of life (four items). All items were scored from 0 to 4 , and each of the five scores was calculated as the sum of the items included [27].

Figure 2 demonstrate an improvement of patients status overall, in all the 5 parameters evaluated by KOOS scale. Figure 3 represents the 5 parameters distinguished (Symptoms, Pain, Daily Activity, Sport, Quality of Life) and one can observe a progressive improvement of the parameters.

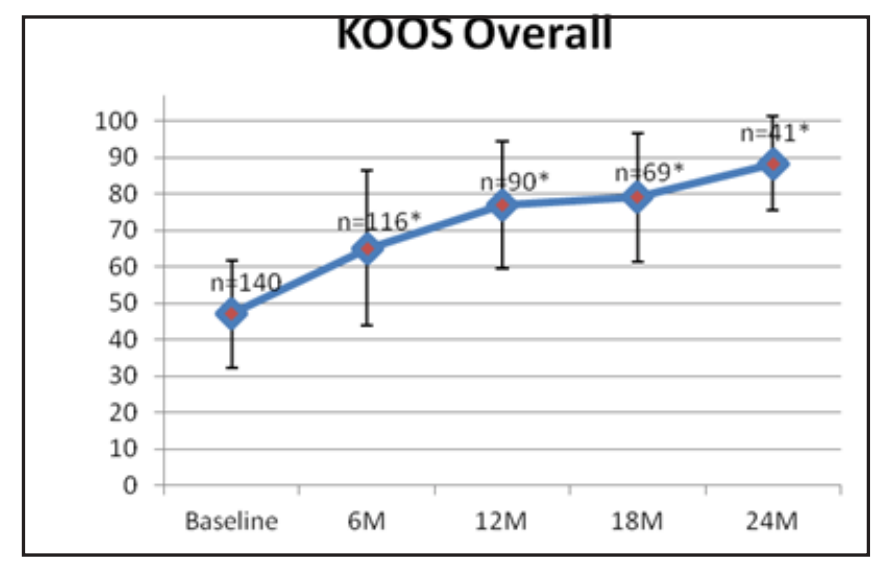

Fig. 2. Primary endpoint: KOOS Overall

$* p<0.05$ (difference from baseline was statistical significantly)

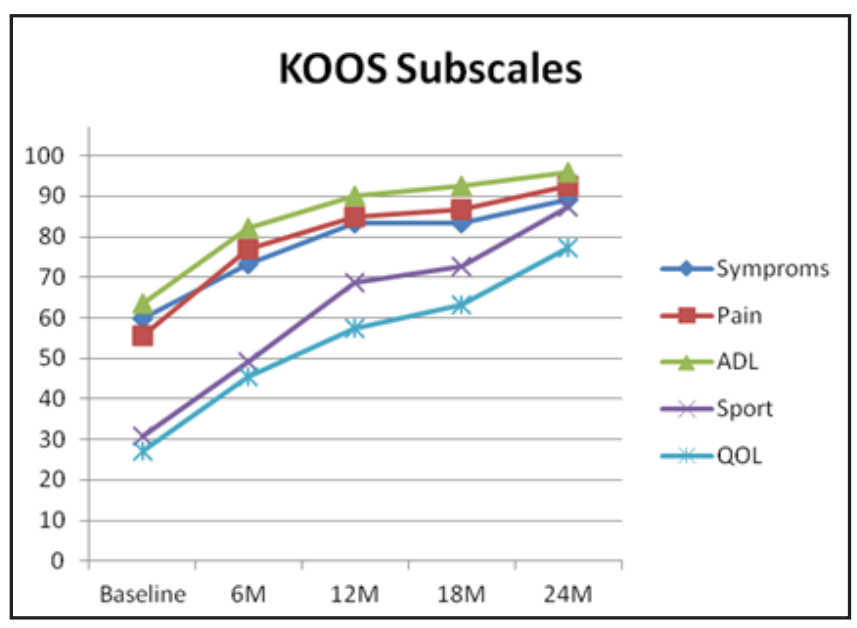

Fig. 3. KOOS subscales (see text for abbreviations) 
Comparing ICRS III grade lesions vs. ICRS IV grade lesion (fig. 4 and fig. 5), one can observe that the KOOS scores have the same ascendant trend in both scales, regardless of the severity of the lesion. All the results have proven an increasement in patient's status and quality of life.

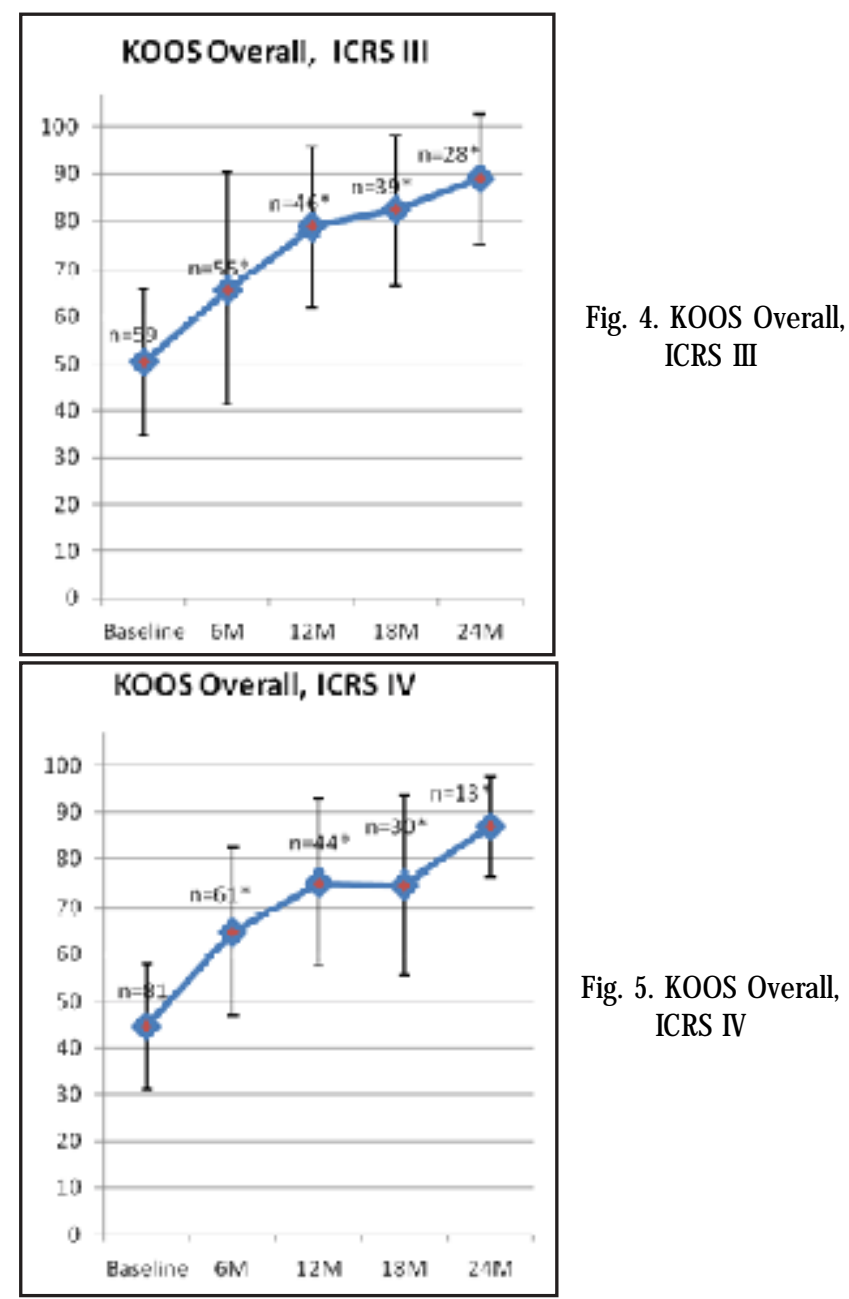

It is well known that the function of the knee is related to the amount of the menisci which is left after meniscectomy.

In 1948, Fairbank [28] reported the clinical outcomes of 107 patients after total meniscectomy and found that the majority had progressive flattening of the condyle, narrowing of the joint space and ridge formation.

Recent studies have proven that the knee instability after $A C L$ rupture might lead to an increased risk of meniscal tears and premature degenerative changes of the knee joint.

Artificial ligament LARS that we used represents a synthetic scaffold that used to augment the repaired native soft tissue. It is an internal fixator which allows ingrowth of tissue in the intra-articular part, so it is permeable to the healing process. The scaffold uses a design which mimics the native anatomic ligament fibers: intra-articular longitudinal fibers resist fatigue and allow fibroblastic ingrowth, whilst extra-articular woven fibers provide strength and resistance to elongation. LARS requires no tissue harvesting and it will not lead to further loss of proprioception, as compared to other procedures of $\mathrm{ACL}$ reconstruction [29].

Treatment of articular cartilage lesions in the knee consists of a wide range of techniques that are currently practiced, ranging from conservative measures through various types of surgical techniques [30]. The end result of these methods is usually a fibrous repair tissue (fibrocartilage), which lacks the biomechanical characteristics of hyaline cartilage that are necessary to withstand the compressive forces distributed across the knee [31].

Autologous cartilage using a technique with tridimensional solid support (HYAFF-11) Hyalograft $\mathrm{C}$ is a tissue-engineering approach for the treatment of knee cartilage defects involving the implantation of laboratory expanded autologous chondrocytes grown on a threedimensional hyaluronan based scaffold. We used it in only 7 cases, as the product was retreated from the market.

Autologous implant of chondrocytes using the arthroscopic pathway - Chondrotissue (BioTissue AG, Zurich, Switzerland)-collagen sterile matrix chondrotissueabsorbable non-woven polyglycolic acid textile treated with hyaluronic acid.

The chondrotissue scaffold is an absorbable non-woven felt of pure polyglycolic acid (PGA) combined with fermentative and freeze-dried hyaluronic acid (average molecular weight, 1,200 kDa) and a porosity of approximately $70 \%$. The matrix is like a sponge and retains the clot and the progenitor cells inside the defect, inducing hemostasis and protecting the subjacent tissue. The mechanical stability ensures handling and safe fixation by glue with fibrin, trans-osseous or trans-cartilage suture or absorbable brooches. The mesenchymal stem cells derived from bone marrow are flushed into the cartilage defect by the scaffold, while their differentiation into chondrocytic cells is supported bythe hyaluronic acid. In the ovine model, the combination of an absorbable textile scaffold and hyaluronan has been shown to accelerate and improve repair with cartilage matrix rich in type II collagen, compared to microfracture alone [32-36].

The involvement of subchondral bone in many of these lesions requires the development of cell-free treatment strategies focused on the entire osteochondral unit, as to regenerate both components of the osteochondral unit and to restore the articular surface.

Agili-C is such a novel, biphasic osteochondral implant composed of modified aragonite. The implant is acellular, biodegradable, capable of bone marrow mesenchymal stem-cell recruitment, preclusive of inappropriate fibroblastic ingrowth, and capable of facilitating functional hyaline cartilage and bone regeneration. The implant consists of a natural crystalline aragonite, derived from corals [37-40].

\section{Conclusions}

We consider LARS artificial ligament to be a facile and timely solution for $A C L$ reconstruction with a faster recovery period compared to other techniques. It is, in our opinion, a very good solution for athletes and sport professionals due to its resistance, reliability and stability, and the short rehabilitation period. It is also important to note that there is no need to harvesta ligament in order to complete the procedure. Like the bone-patellar tendonbone (BTB) graft and hamstring technique, LARS artificial ligament displays both advantages and disadvantages. The LARS ligament relies on both the feasibility and the ability to repair the native torn ligament.

The combination of microfracture and Chondrotissue is, in our opinion, an interesting option for the treatment of large cartilage defects.

Agili-C is an innovative implant, with a lot of characteristics that give a lot of hope for the future of osteochondral lesions treatment. Once in place, osteointegration and osteo-conduction begin as the scaffold pores are gradually filled with avascularised fibro- 
mesenchymal tissue rich in osteo-progenitor cells. The implant promotes formation of hyaline cartilage from the periphery towards the center.

\section{References}

1.PATRASCU, J.M., VERMESAN, D., MIOC, M.L., LAZUREANU, V., FLORESCU S., TARULLO, A., TATULLO, S., ABBINANTE, A., CAPRIO, M., CAGIANO, R., HARAGUS, H., Eur. Rev. Med. Pharmacol. Sci., 18, no. 24, 2014, p. 3899.

2.HERWIG, J., EGNER, E., BUDDECKE, E., Annals of the Rheumatic Diseases, 43, 1984, pp. 635-640.

3.KON, E., ROBINSON, D., VERDONK, P., DROBNIC, M., PATRASCU, J.M., OLIVER DULIC, O., GAVRILOVIC, G., FILARDO, G., Injury, Int. J. Care Injured, 47S6, 2016, pp. S27-S32.

4.FALAH, M., NIERENBERG, G., SOUDRY, M., HAYDEN, M., VOLPIN, G., Int. Orthop., 34, no. 5, 2010, p. 621, DOI: 10.1007/s00264-010-0959$\mathrm{y}$.

5.PATRASCU, J.M., AMARANDEI, M., KUN, K.N., BORUGA, 0. TOTOREAN, A., ANDOR, B., FLORESCU, S., Rom. J . Morphol. Embryol., 55, 3 Suppl., 2014, p. 1231.

6.PATRASCU, J.M., FREYMANN, U., KAPS, C., POENARU, D. V., J ournal of Bone And J oint Surgery-British, 92B, no. 8, 2010, p. 1160.

7.ANDOR, B., DANCIU, C., ALEXA, E., ZUPKO, I., HOGEA, E., CIOCA, A., CORICOVAC, D., PINZARU, I., PATRASCU, J., MIOC, M., CRISTINA, R. T., SOICA, C., DEHELEAN, C., Evidence-Based Complementary and Alternative Medicine, Article ID 7638542, 2016, pp. 1-8. 8.HOGEA, L.M., NUSSBAUM, L.A., CHIRIAC, D.V., AGEU, L.S., ANDREESCU, N.I., GRIGORAS, M.L., FOLESCU, R., BREDICEAN, A.C., PUIU, M., ROSCA, E.C.I., SIMU, M.A., LEVAI, C.M. Rom. J. Morphol. Embryol, 58, no. 3, 2017, p. 767.

9.NUSSBAUM, L.A., HOGEA, L.M., CHIRIAC, D.V., GRIGORAS, M.L., FOLESCU, R., BREDICEAN, A.C., ROSCA, E.C.I., MUNCAN, B., NUSSBAUM, L.M., SIMU, M.A., LEVAI, C.M., Rom. J. Morphol. Embryol, 58, no. 4, 2017, p. 1435.

10.NUSSBAUM, L.A., OGODESCU A., HOGEA, L.M., NUSSBAUM, L., ZETU, I., Rev. de Cercetare si Interventie Soc., 56, 2017, p. 114.

11.NUSSBAUM, L.A., HOGEA, L.M., ANDREESCU, N.I., GRADINARU, R.C., PUIU, M., TODICA, A., Rom. J . Morphol. Embryol, 57, no 3, 2016, p. 959.

12.CHIRIAC, D.V., HOGEA, L.M., BREDICEAN, A.C., REDNIC, R., NUSSBAUM, L.A., HOGEA, G.B., GRIGORAS, M.L., Rom. J. Morphol. Embryol, 58, no 3, 2017, p. 1023.

13.ALBAI, A., SIMA, A., PAPAVA, I., ROMAN, D., ANDOR, B., GAFENCU, M., Patient Preference and Adherence, 11, 2017, p. 1237.

14.SIMA, A., TIMAR, R., VLAD, A., TIMAR, B., ROSU, M., DAN, I., SIRLI, R., POPESCU, A., SPOREA, I., Wiener Klinische Wochenschrift, 126, no. 11-12, 2014, p. 335.

15.BALASA, R.I., SIMU, M., VOIDOZAN, S., et al., CNS\&Neurological Disorders-Drug Targets, 16, no. 9, 2017, p. 1018.

16.POPESCU, S., TIMAR, B, BADERCA, F., Clinical Intervention In Aging, 11, 2016, p. 313.

17.ROSCA, E.C., SIMU M., Acta Neurologica Belgica, 118, no 1, 2018, p. 123.

18.NUSSABUM, L.A., HOGEA, L.M., CHIRIAC, D.V., Rom. J. Morphol. Embryol, 58, no. 4, 2017, p. 1435.
19.MOISE, M., BURUIANU, M., ILIE, C., ZAMFIR, C.L., FOLESCU, R., MOTOC, A.G.M., Rom. J. Morphol. Embryol, 54, no. 4, 2013, p. 961. 20.FAUR, A.C., SAS, I., MOTOC, A.G.M., CORNIANU, M., ZAMFIR, C.L., LAZAR, D.C., FOLESCU, R., Rom. J. Morphol. Embryol., 56, no. 4, 2015, p. 1429.

21.BUDA, V., ANDOR, M., LEDETI, A., LEDETI, I., VLASE, G., VLASE, T., CRISTESCU, C., VOICU, M., SUCIU, L., TOMESCU, M.C., International Journal of Molecular Sciences, 18, no. 1, 2017, p. 3.

22.BUDA, V., ANDOR, M., CRISTESCU, C., VOICU, M., SUCIU, L., MUNTEAN, C., CRETU, O., BALBATA, D.E., GHEORGHIU, C.M., TOMESCU, M. C., Farmacia, 64, no. 3, 2016, p. 382.

23.BUDA, V., ANDOR, M., PETRESCU, L., CRISTESCU, C., BAIBATA, E., VOICU, M., MUNTEANU, M., CITU, I., MUNTEAN, C., CRETU, O., TOMESCU, M.C., Int. J. Mol. Sci., 18, no. 2, 2017, p. 348.

24.CRETU, O.M., HUT, E.F., DAN, R.G., SIMA, L.V., BLIDISEL, C.I.A., LIGHEZAN, D.F., MUNTEANU, M., RAPIU, I.M., Rom. J. Morphol. Embryol., 58, no. 4, 2017, p. 1295.

25.ROSCA , C., MUNTEANU, M., TAMASOI, I., Acta Ophtalmologica, 94, no. 6, 2016, p. 625.

26.NEAMTU, C., TOTOLICI, B.D., CRETU, O.M., STANESCU, C., ARDELEAN, A., BADEA, O., PRIBAC, G.C., CIOBANU, M.O., MATEESCU, G.O., MOGOANTA, S.S., Rom. J. Morphol. Embryol., 58, no. 1, 2017, p. 235.

27.ROOS, E. M., ROOS, H.P., LOHMANDER, L. S., EKDAL, C., BEYNNON, B. D., J ournal of Orthopedic \& Sports Physical Therapy, 28, no. 2, 1998, p. 88.

28.FAIRBANK, T.J ., J. Bone J oint Surg. Br., 30B, no. 4, 1948, p. 664. 29.MACHOTKA, Z., SCARBOROUGH, I., DUNCAN, W., KUMAR, S., PERRATON, L., Sports Med. Arthrosc. Rehabil. Ther. Technol., 2, 2010, p. 29.

30.CRAIG, W., DAVID, J.W., MING, H.Z., Musculoskelet. Res., 7, no. 3\&4, 2003, p. 157

31.FALAH, M., NIERENBERG, G., SOUDRY, M., HAYDEN, M., VOLPIN, G., Int. Orthop., 34, no. 5, 2010, p. 621.

32.ANDOR, B., PATRASCU, J. M., FLORESCU, S., COJ OCARU, D., SANDESC, M., BORCAN, F., BORUGA, O., BOLINTINEANU, S., Mat. Plast., 53, no. 1, 2016, p. 120.

33.HOGEA, L.M., HOGEA, B.G., NUSSBAUM, L.A., etal, Rom. J. Morphol. Embryol, 58, no. 1, 2017, p. 175.

34.CHIRIAC, V.D., HOGEA L.M., BREDICEAN A.C., et al, Rom. J. Morphol. Embryol, 58, no. 3, 2017, p. 1023.

35.HOGEA, B.G., PATRASCU, J.M. J R., SANDESC, M.A., Rom. J. Morphol. Embryol., 59, no. 3, 2018, p. 741.

36.HJELLE, K., SOLHEIM, E., STRAND, T., MURI, R., BRITTBERG, M., Arthroscopy, 18, 2002, pp. 730-734.

37.FOSTER, T.E, PUSKAS, B.L, MANDELBAUM, B.R., GERHARDT, M.B., RODEO, S.A., Am. J. Sports Med., 37, 2009, pp. 2259-2272.

38.KON, E., ROBINSON, D., VERDONK, P., DROBNIC, M., PATRASCU, J.M., DULIC, O., GAVRILOVIC, G., FILARDO, G., Injury, Int. J. Care Injured, 47, S6, 2016, S27-S32.

39.POPESCU, M.R. ,ZUGUN, F.E., COJ OCARU, E., TOCAN, L., FOLESCU, R., ZAMFIR, C.L., Rom. J. Morphol. Embryol., 54, no. 2, 2013, p. 399. 40.ALEXA, A.I., CANTEMIR, A., ANTIOCH, I., ALMUS, I.M., COJOCARU, S., GARDIKIOTIS, R., LUCA, A., FILIP, M.A., ABABEI, D.C., ZAMFIR, C.L., Rev. Chim. (Bucharest), 68, no. 2, 2017, p. 350.

Manuscript received: 12.07 .2018 